\title{
Pemilihan Lokasi Pengolahaan Air Limbah di Kota Surabaya Berdasarkan Unit Pengembangan Menggunakan Metode Spatial Multi Criteria Evaluation
}

\author{
Gatot Cakra Wiguna, Agung Budi Cahyono \\ Departemen Teknik Geomatika, Fakultas Teknik Sipil dan Perencanaan, Institut Teknologi Sepuluh \\ Nopember (ITS) \\ e-mail: agungbc@geodesy.its.ac.id
}

\begin{abstract}
Abstrak-Sanitasi merupakan salah satu permasalahan yang timbul ditengah-tengah masyarakat, umumnya terjadi dikawasan perkotaan. Kota Surabaya merupakan kota terbesar kedua dimana jumlah penduduknya mencapai lebih dari dua juta jiwa. Hal tersebut yang mendasari pentingnya sanitasi bagi masyarakat perkotaan. Penyediaan sistem pengolahan air limbah dapat mengendalikan permasalahan sanitasi yang ada dimasyarakat. Oleh karena itu penelitian ini bertujuan untuk menentukan lokasi pengolahan air limbah di Kota Surabaya. Salah satu metode dalam menentukan kawasan yang sesuai untuk pengolahan air limbah adalah dengan menggunakan metode Spatial Multi-Criteria Evaluation yaitu suatu teknik yang membantu untuk membuat keputusan (Decision Support System). Pada penelitian ini digunakan berbagai kriteria diantaranya jenis tanah, tata guna lahan, badan air penerima, kawasan rawan banjir, dan faktor jarak terhadap pusat kota. Sehingga didapatkan nilai kesesuaian lokasi IPAL dengan mengklasifikasikan menjadi lima kriteria yaitu kesesuaian sangat tinggi, tinggi, menengah, rendah dan tidak sesuai. Berdasarkan analisa yang dilakukan pada penelitian ini didapatkan daerah yang sesuai untuk lokasi IPAL terletak pada unit pengembangan XII Sambikerep dengan tingkat presentase kesesuaian sangat tinggi sebesar $20 \%$, tinggi $13 \%$, menengah $24 \%$, rendah $20 \%$, tidak sesuai $23 \%$.
\end{abstract}

Kata Kunci-Sanitasi, SMCE, Sistem Informasi Geografis, DSS.

\section{PENDAHULUAN}

$\mathrm{S}$ ANITASI merupakan usaha kesehatan dengan memelihara dan melindungi kebersihan lingkungan, seperti meyediakan air bersih untuk keperluan mencuci tangan, menyediakan tempat sampah dan menyediakan untuk mewadahi air limbah agar tidak dibuang sembarangan. Sistem sanitasi dibagi menjadi sistem terpusat dan sistem setempat. Sistem setempat dibagi menjadi sistem individu, MCK, dan komunal 2-10 RT. Sedangkan sistem terpusat terdiri dari skala permukiman [1].

Target 100-0-100 yang mulai dikenalkan oleh Kementerian PU adalah target yang tercantum dalam rancangan RPJMN (Rencana Pembangunan Jangka Menengah Nasional) 20152019 menyatakan bahwa Target 100\% akses air minum, 0\% kawasan permukiman kumuh, dan 100\% akses sanitasi layak yang meningkatnya akses penduduk terhadap sanitasi layak (air limbah domestik, sampah dan drainase lingkungan) menjadi 100 persen pada tingkat kebutuhan dasar yaitu untuk sarana prasarana pengelolaan air limbah domestik dengan pembangunan dan peningkatan infrastruktur air limbah (IPAL) sistem terpusat skala kota, kawasan, dan komunal di 438 Kota/Kabupaten (melayani 34 juta jiwa) [1].

Dengan demikian perlu dilakukan penelitian untuk mengetahui lokasi pembangunan IPAL terpusat di Kota Surabaya dengan metode spatial multi criteria evaluation dimana metode ini dapat memberikan informasi dan gambaran yang lengkap dalam pemilihan lokasi pengolahan air limbah.

\section{METODOLOGI PENELITIAN}

\section{A. Lokasi Penelitian}

Lokasi kegiatan penelitian ini berlokasi di kota Surabaya yang terbagi menjadi enam unit pengembangan sesuai dengan rencana pengembangan sistem pengolahan air limbah perkotaan berdasarkan rencana tata ruang wilayah (RTRW).

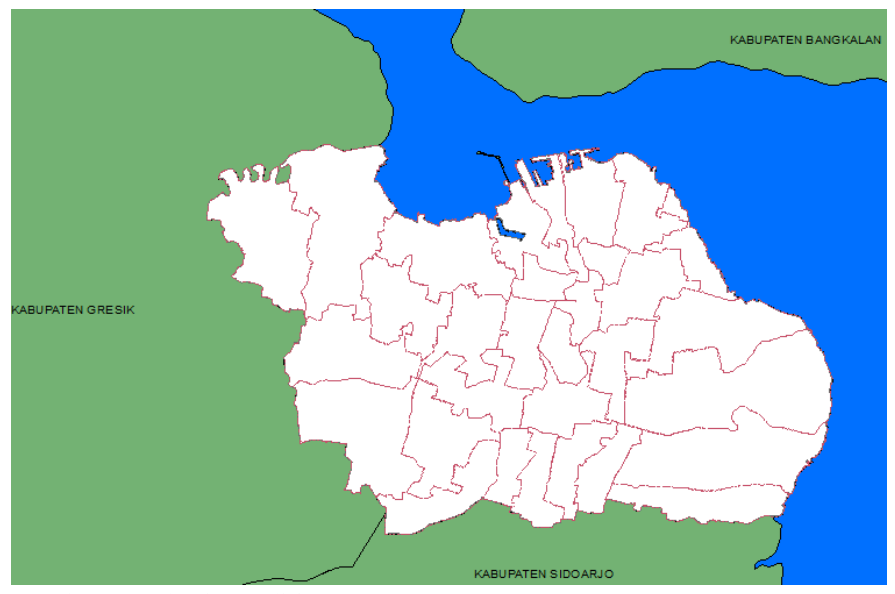

Gambar 1. Lokasi Penelitian

\section{B. Data dan Peralatan yang Digunakan}

Pada penelitiaan ini, data yang digunakan yaitu :

a. Peta digital kawasan kota Surabaya, skala 1:50.000 tahun 2014 
b. Peta jenis tanah kota Surabaya, skala 1:50.000 tahun 2014

c. Peta kawasan rawan banjir kota Surabaya, skala 1:50.000 tahun 2014

d. Peta tataguna lahan kota Surabaya, skala 1:50.000 tahun 2014

e. Peta badan air kota Surabaya, skala 1:50.000 tahun 2014

f. Peta RTRW kota Surabaya, skala 1:50.000 tahun 2014 sedangkan peralatan yang digunakan pada penelitian ini adalah

a. Software ILWIS 3.8.5

b. Software ArcGIS 10.3

\section{Tahapan Penelitian}

Tahapan yang akan dilakukan dalam penelitian studi ini adalah seperti pada diagram alir berikut ini :

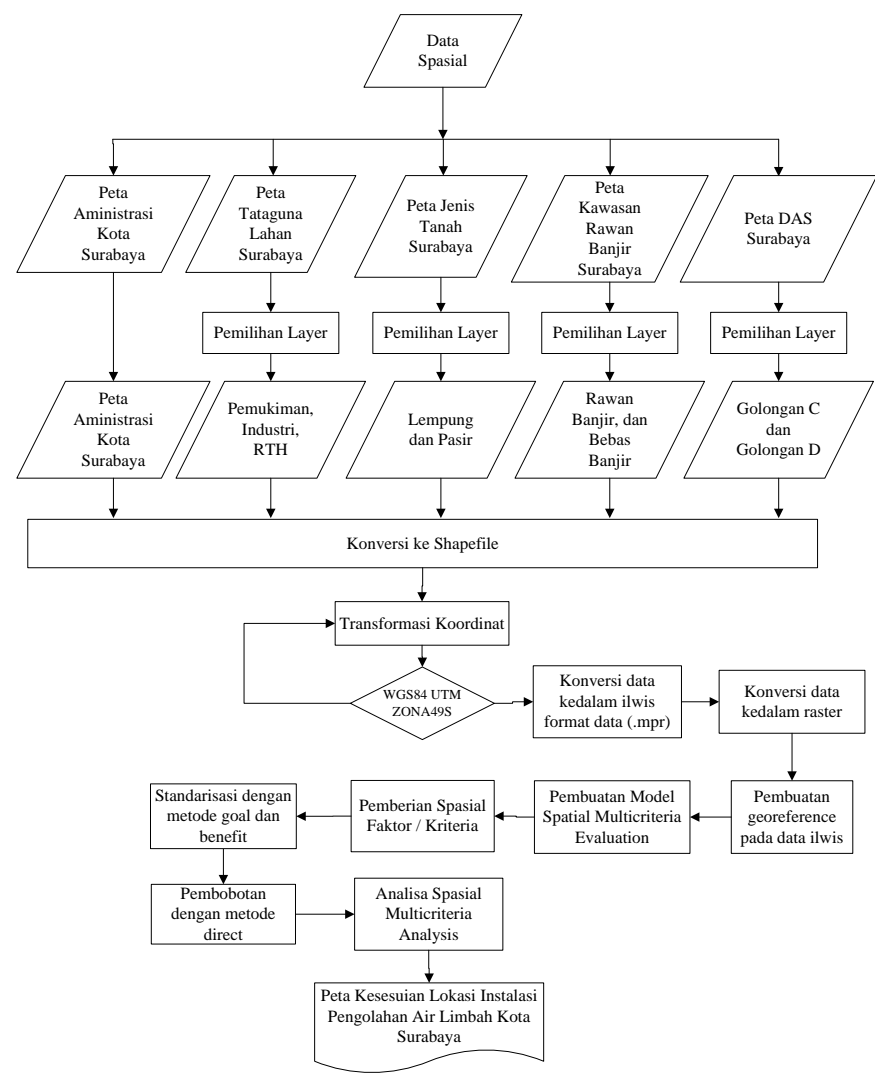

Gambar 2. Diagram Alir

a. Tahapan Persiapan

Pada tahap persiapan dilakukan pemilihan layer untuk mendapatkan kriteria-kriteria yang dibutuhkan, kriteria tersebut dapat dilihat pada tabel 1 berikut.

Tabel 1.

Data Vektor

\begin{tabular}{|c|c|c|c|}
\hline No & Kriteria & Sumber Data & Skala \\
\hline a. & $\begin{array}{l}\text { Persebaran jenis tanah } \\
\text { lempung dan pasir }\end{array}$ & Peta jenis tanah & $1: 50.000$ \\
\hline b. & $\begin{array}{c}\text { Persebaran kawasan rawan } \\
\text { banjir dan kawasan bebas } \\
\text { banjir }\end{array}$ & $\begin{array}{c}\text { Peta kawasan rawan } \\
\text { banjir }\end{array}$ & $1: 50.000$ \\
\hline
\end{tabular}

c. Persebaran badan air penerima gol $\mathrm{c}$ dan gol d

Persebaran daerah

d. pemukiman, industri, dan $\mathrm{RTH}$

$$
\begin{array}{cc}
\text { Peta DAS kota } & 1: 50.000 \\
\quad \text { Surabaya } & \\
\text { Peta tataguna lahan } & 1: 50.000
\end{array}
$$

Selanjutnya dilakukan transformasi koordinat kedalam Sistem Proyeksi WGS84 dengan sistem koordinat UTM Zona 49S. Setelah dilakukan transformasi, data diubah kedalam format raster menggunakan software ILWIS 3.8.5. dan didapatkan hasil raster seperti gambar dibawah ini, dimana warna selain merah menggambarkan objek dari parameter yang dibutuhkan.

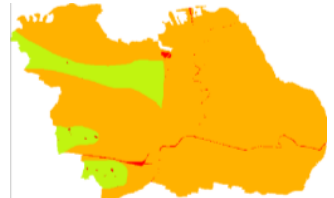

(a)

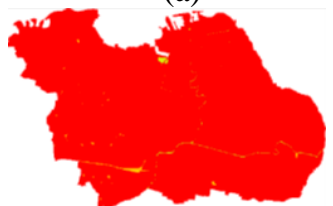

(c)

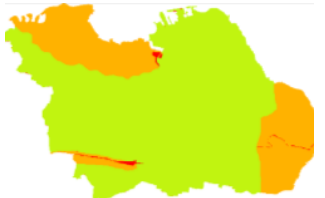

(b)

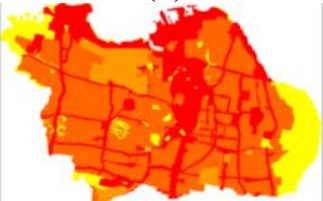

(d)

Gambar 3. Pengolahan Peta raster

\section{b. Pengolahan Data}

Pada kasus pemilihan lokasi IPAL dilakukan standarisasi dengan jenis "Benefit" karena semakin jauh atau tinggi nilai yang dimiliki maka lokasi tersebut semakin baik. Kemudian untuk metode pilih "Goal" dan masukkan nilai 10 untuk X2 sebagai nilai maksimum [2].

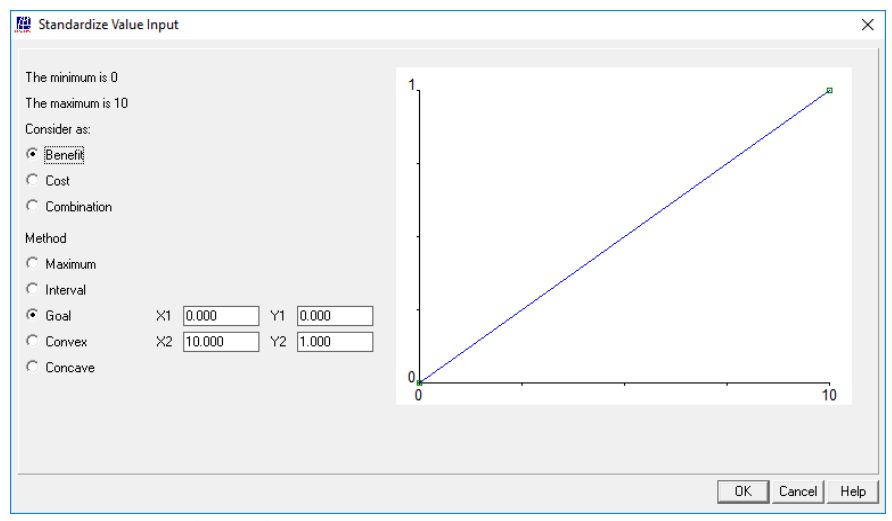

Gambar 4. Standarisasi

Tahapan disain melibatkan standariasai dan pembobotan dari semua faktor yang dipertimbangkan dalam analisa. Setiap kriteria diwakili oleh sebuah peta. Untuk analisis pengambilan keputusan, nilai dan kelas dari semua peta harus diubah menjadi skala yang sama yang disebut "utility". "Utility" adalah ukuran penilaian dari pembuat keputusan dengan mempertimbangkan kriteria tertentu, dan berhubungan dengan nilai (diukur dalam skala dari 0 sampai 1) transformasi seperti ini biasa disebut standardisasi [3]. 
Setiap kriteria dan faktor diberikan nilai bobot sesuai dengan prioritasnya masing-masing. Hal ini didasarkan atas tingkat kesesuain faktor terhadap lokasi pengolahan air limbah. Tabel 2.

Nilai Bobot Parameter yang Digunakan

\begin{tabular}{|c|c|c|c|}
\hline $\mathrm{W}_{\mathrm{k}}$ & Kriteria & Faktor & $\mathrm{W}_{\mathrm{f}}$ \\
\hline 0,190 & $\begin{array}{l}\text { Badan Air } \\
\text { Penerima }\end{array}$ & Badan Air Penerima Gol D & 0,588 \\
\hline \multirow{4}{*}{0,238} & \multirow{4}{*}{ Tata Guna Lahan } & Badan Air Penerima Gol C & 0,412 \\
\hline & & RTH & 0,500 \\
\hline & & Industri & 0,300 \\
\hline & & Pemukiman & 0,200 \\
\hline \multirow[t]{2}{*}{0,143} & \multirow[t]{2}{*}{$\begin{array}{l}\text { Kawasan Rawan } \\
\text { Banjir }\end{array}$} & Bebas Banjir & 0,667 \\
\hline & & Rawan Banjir & 0,333 \\
\hline \multirow[t]{4}{*}{0,095} & \multirow[t]{4}{*}{ Jenis Tanah } & Tanah Lempung & 0,500 \\
\hline & & Tanah Lanau & 0,250 \\
\hline & & Tanah Lanau-Pasir & 0,150 \\
\hline & & Tanah Pasir & 0,100 \\
\hline \multirow[t]{2}{*}{0,333} & \multirow[t]{2}{*}{ Faktor Jarak } & $\begin{array}{c}\text { Jangkauan } 6 \text { km ke Pusat } \\
\text { Kota }\end{array}$ & 0,529 \\
\hline & & $\begin{array}{c}\text { Jangkauan } 9 \mathrm{~km} \text { ke Pusat } \\
\text { Kota }\end{array}$ & 0,471 \\
\hline
\end{tabular}

Tabel diatas merupakan nilai bobot yang digunakan untuk proses analisa spasial. Setelah dilakukan standarisasi dan diberikan nilai bobot maka dilakukan pembobotan menggunakan metode direct dengan rumus :

$$
W_{\mathrm{k}} x W_{f}=N_{f}
$$

Keterangan :

$W_{\mathrm{k}}$ : Bobot kriteria

$W_{f}$ : Bobot faktor

$N_{f}$ : Nilai faktor

\section{$\Sigma N_{f}=$ Nilai Kesesuaian}

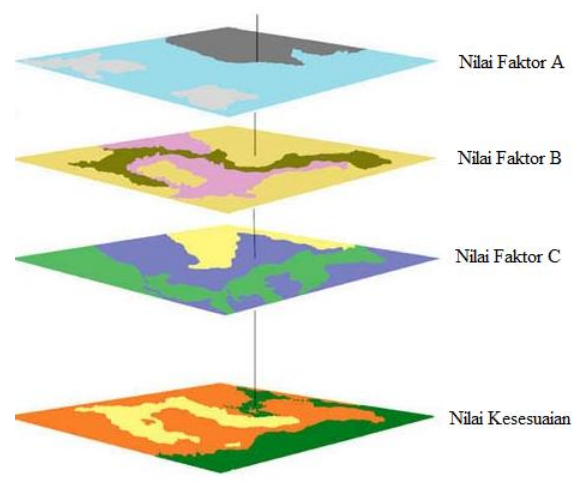

Gambar 5. Overlay dan Pembobotan Metode Direct [4]

Gambar diatas adalah proses analisa Spatial Multicriteria Evaluation dan pembobotan untuk mendapatkan nilai kesesuaian yang merupakan hasil overlay dari nilai-nilai faktor.

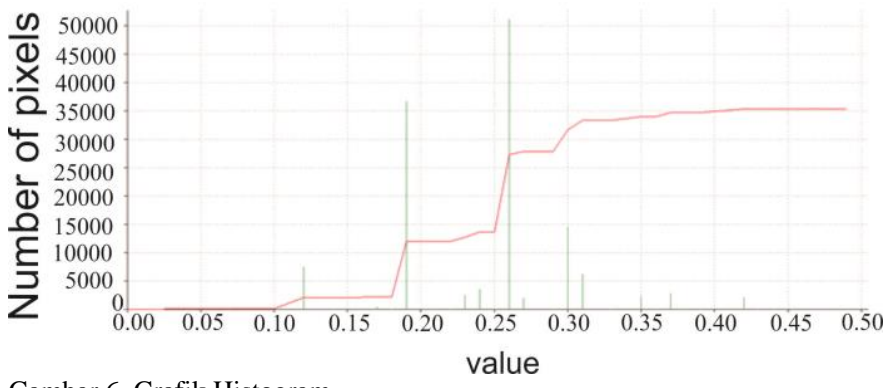

Gambar 6. Grafik Histogram

Hasil dari nilai kesesuaian dapat dilihat pada gambar 6 . Dimana nilai kesesuaian berbanding lurus terhadap nilai pixel.

\section{HASIL DAN ANALISA}

\section{A. Hasil dan Analisa Pengolahan Data}

Berdasarkan hasil dan analisa yang dilakukan didapatkan peta kesesuaian lokasi Instalasi Pengolahan Air Limbah di Kota Surabaya dengan lima kriteria seperti yang tertera pada tabel 3 dibawah ini.

Tabel 3.

Nilai Kesesuaian

\begin{tabular}{lcl}
\hline \hline Kelas & $\begin{array}{c}\text { Nilai Kesesuaian } \\
\text { (pixel) }\end{array}$ & \multicolumn{1}{c}{ Deskripsi } \\
\hline 1 & $1-16$ & Tidak Sesuai untuk Lokasi IPAL \\
2 & $16-23$ & $\begin{array}{l}\text { Kesesuaian Rendah untuk Lokasi } \\
\text { IPAL }\end{array}$ \\
3 & $23-28$ & $\begin{array}{l}\text { Kesesuaian Sedang untuk Lokasi } \\
\text { IPAL }\end{array}$ \\
4 & $28-34$ & $\begin{array}{l}\text { Kesesuaian Tinggi untuk Lokasi } \\
\text { IPAL } \\
\text { Kesesuaian Sangat Tinggi untuk } \\
\text { Lokasi IPAL }\end{array}$ \\
\hline \hline
\end{tabular}

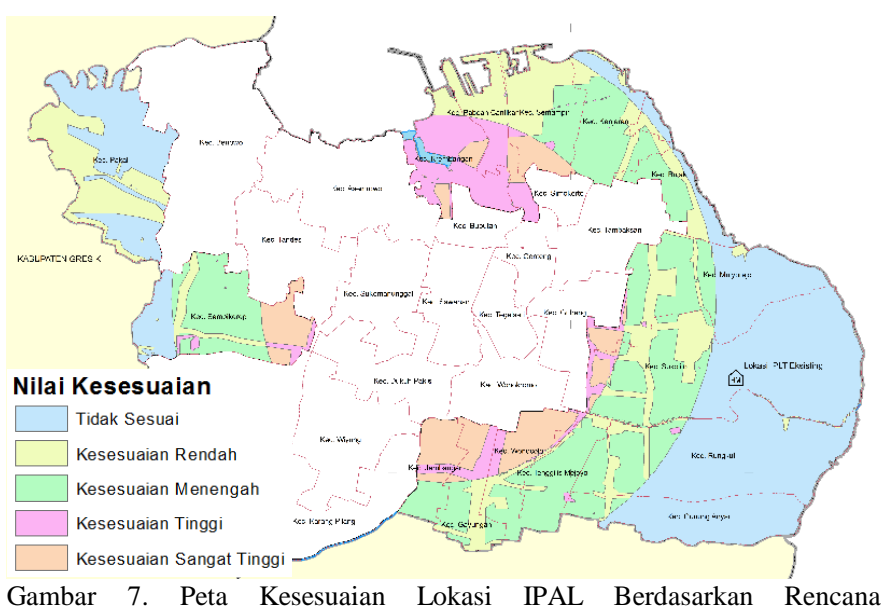

Pengembangan Sistem Air Limbah

Berikut ini adalah luas area kesesuaian pada Unit Pengembangan yang diperuntukan untuk pengembangan sistem pengolahan air limbah di Kota Surabaya yang dapat dilihat pada tabel 4 . 
Tabel 4.

Luas Kesesuaian

\begin{tabular}{lc}
\hline \multicolumn{1}{c}{ Klasifikasi } & Luas (ha) \\
\hline Kesesuaian Sangat Tinggi & 542,595 \\
Kesesuaian Tinggi & $3.583,622$ \\
Kesesuaian Menengah & $7.385,859$ \\
Kesesuaian Rendah & $5.429,107$ \\
Tidak Sesuai & 208,125 \\
\hline \hline
\end{tabular}

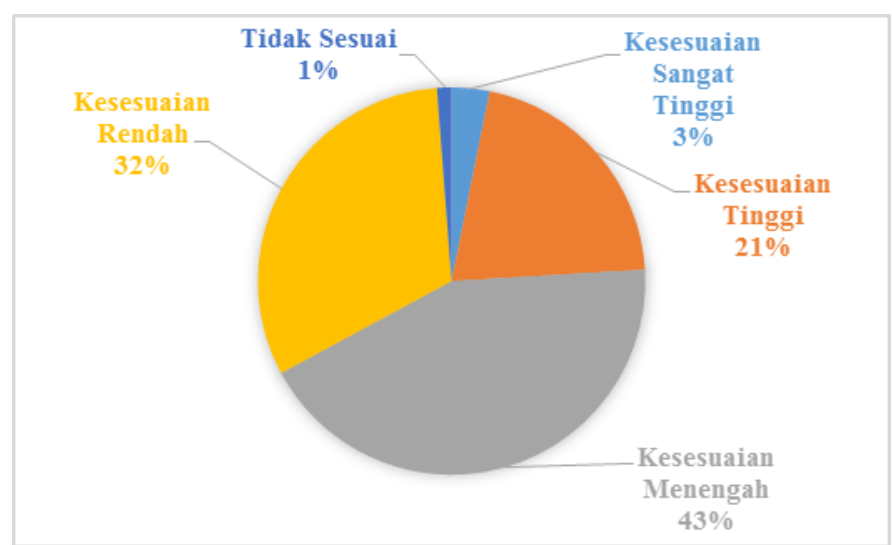

Gambar 8. Diagram Kesesuaian Lahan IPAL

Dari hasil perhitungan luasan didapatkan nilai presentase dari masing-masing nilai klasifikasi. Yaitu kawasan dengan kesesuaian sangat tinggi sebesar $3 \%$, Tinggi $21 \%$, menengah $43 \%$, rendah $32 \%$, dan tidak sesuai $1 \%$.

\section{KESIMPULAN}

Berdasarkan hasil penelitian aplikasi metode spatial multi criteria evaluation untuk penentuan lokasi IPAL di Kota Surabaya dapat disimpulkan bahwa :

1. Unit pengembangan yang memiliki tingkat kesesuaian yang paling tinggi terdapat di Unit Pengembangan I Sambikerep Surabaya.

2. Surabaya memiliki kesesuaian kawasan pengelolaan air limbah dengan tingkat kesesuaian sangat tinggi sebesar $3 \%$ dengan luas 542,595 ha, dan kesesuaian tinggi sebesar $21 \%$ dengan luas wilayah 3.583,622 ha. Hasil tersebut dapat memberikan gambaran mengenai kawasan yang akan dijadikan lokasi pengolahan air limbah bagi pemerintah.

\section{UCAPAN TERIMA KASIH}

Penulis G.C mengucapkan terima kasih kepada Badan Perencanaan Pembangunan Kota Surabaya yang telah memberikan dukungan dan bantuan berupa data-data yang dibutuhkan dalam penelitian studi ini sehingga penelitian ini berjalan dengan lancar.

\section{DAFTAR PUSTAKA}

[1] A. Sofyan, I., Ika, F., Eri, A., \& Ruslan, Sistem Pengolahan Air Limbah Domestik Terpusat Skala Pemukiman. Jakarta: Kementerian Pekerjaan Umum dan Perumahan Rakyat, 2016.

[2] J. Wibowo, A., \& M.Semedi, "Model Spasial dengan SMCE untuk Kesesuaian Kawasan Industri (Studi Kasus Di Kota Serang)," pp. 50-59, 2011.

[3] S. Ferreti, V., \& Pomarico, "An integrated approach for studing the land suitability for ecological corridors through spatial multicriteria evaluations. In Environment, Development and Sustainability," Springer, 2012.

[4] J. Graaf, G., Marttin, F., Jenness, "Geographic Information Systems in Fisheries Management and Planning Technical manual," 2003. 